\title{
A Review of the Mechanism of Action of Cyclosporine A: The Role of Cyclosporine A in Dry Eye Disease and Recent Formulation Developments
}

This article was published in the following Dove Press journal: Clinical Ophthalmology

\author{
Laura M Periman (iD) \\ Francis S Mah ${ }^{2}$ \\ Paul M Karpecki (iD) ${ }^{3}$ \\ 'Periman Eye Institute, Seattle, WA, USA; \\ ${ }^{2}$ Scripps Health, La Jolla, CA, USA; \\ ${ }^{3}$ Kentucky Eye Institute, Lexington, \\ KY, USA
}

\begin{abstract}
Dry eye disease (DED) is a multifactorial disease of the ocular surface and tear film that has gained awareness as a public health problem. Characteristics of DED include tear film instability, hyperosmolarity, and ocular surface inflammation, which can occur independently or may be a sequela of numerous ocular diseases, ocular surgery or contact lens wear. Much has been learned about the impact of the disease to help affected individuals who report symptoms of poor vision, pain, and tearing. Recently, new research highlights the importance of the role of ocular surface inflammation and damage in DED-leading to a vicious cycle of inflammation as well as loss of tear film homeostasis. DED immunopathophysiology is characterized by four stages: initiation, amplification, recruitment, and reinitiation. Cyclosporine is proven to be a valuable ophthalmic therapeutic for DED through its immunomodulatory actions and regulation of the adaptive immune response. Cyclosporine mechanism of action is well described in the published literature and the myriad of benefits in all four stages lend a broad-based immunomodulatory function particularly suitable for addressing DED. Furthermore, cyclosporine has unique goblet cell density improvement capabilities as well as anti-apoptotic properties. Topical formulations of cyclosporine are centered around addressing the highly lipophilic nature of the molecule. The poor aqueous solubility of cyclosporine traditionally presented technical challenges in drug delivery to the ocular surface. Newer formulations such as cationic emulsions and nanomicellar aqueous solutions address formulation, tissue concentration, and drug delivery challenges.
\end{abstract}

Keywords: dry eye disease, cyclosporine A, emulsion, OTX-101, keratoconjunctivitis sicca

\section{Introduction}

Dry eye disease (DED), also known as keratoconjunctivitis sicca (KCS), is a common disorder of the eye affecting more than 16 million people in the US. ${ }^{1}$ The prevalence of DED ranges from 5\% to $33 \%$ worldwide with increased prevalence among adult women and Asians. ${ }^{1,2}$ Symptoms of DED include discomfort, pain, burning, foreign body sensation, and visual disturbances. ${ }^{1}$ Dry eye negatively affects the patient's quality of life and results in approximately $\$ 4$ billion in annual costs in the US. ${ }^{3,4}$

Dry eye is commonly seen alongside many ocular disorders including glaucoma, cataracts, and refractive errors. ${ }^{5-7}$ Pharmacological treatments for ocular disorders often contain preservatives such as benzalkonium chloride. ${ }^{8}$ These preservatives can cause DED signs and symptoms including decreased epithelial cell integrity, increased
Correspondence: Laura M Periman Periman Eye Institute, Seattle, WA, USA Email dryeyemaster@gmail.com 
epithelial cell apoptosis, eye irritation, and increased risk for ocular allergies and delayed hypersensitivity reactions. ${ }^{8,9}$ Surgical interventions to treat ophthalmic disorders and diseases can also cause dry eye due to the resultant inflammation from the length of time in surgery, incision site disruption to the corneal nerves, and type of post-surgical medication. ${ }^{10-12}$ Post-trabeculectomy patients have elevated tear film osmolarity and symptoms of dry eye; ${ }^{13}$ intraoperative use of lubricating substances can decrease post-surgical dry eye symptoms and treatment with dry eye medication postoperatively can help alleviate surgery-induced dry eye. ${ }^{11,14}$ Dry eye symptoms following cataract surgery occur in $42 \%$, $15 \%$, and $9 \%$ of eyes of patients at 1 week, 1 month, and 3 months after surgery, respectively. ${ }^{12}$ Additionally, new research demonstrates the bilateral impact on the corneal sub-basal nerve complex after cataract surgery, potentially explaining worse dry eye symptoms after cataract surgery on the second eye. ${ }^{10}$

The Tear Film \& Ocular Surface Society Dry Eye Workshop II (TFOS DEWS II) developed an evidencebased definition of DED in recognition of its multifactorial nature. ${ }^{5}$ This key working definition of DED published in 2017 states:

Dry eye is a multifactorial disease of the ocular surface characterized by a loss of homeostasis of the tear film, and accompanied by ocular symptoms, in which tear film instability and hyperosmolarity, ocular surface inflammation and damage, and neurosensory abnormalities play etiological roles. ${ }^{5}$

Activation of ocular surface inflammation is characterized by four broad stages: initiation, amplification, recruitment and damage/self-perpetuation. ${ }^{15}$

In general, the aberrant activation of innate immunity by hyperosmolarity and desiccating stress, along with loss of immunoregulatory controls, results in the conversion to adaptive immunity and sets up a series of vicious circles. ${ }^{15-17}$ This perpetuating cycle of DED is governed by several immunopathophysiological events starting with hyperosmolarity. ${ }^{18}$ Tear hyperosmolarity causes damage to the surface epithelium, beginning with an increase in the mitogen-activated protein kinase (MAPK) and nuclear factor kappa B on the ocular surface. ${ }^{18-21}$ The activation of MAPK triggers the secretion of inflammatory mediators, which facilitate activation of resident dendritic cells and T-cell recruitment to the ocular surface. ${ }^{20,21}$ Additional inflammatory mediators are released from recruited T cells, which compromises the lacrimal functional unit further, adding to tear hyperosmolarity, which further accentuates cellular damage and loss of epithelial and goblet cells-all leading to a progressive cycle of tear film instability and inflammation (Figure 1). ${ }^{18,21}$ Goblet cell loss leads to disturbances in mucin production and loss of immunoregulation from transforming growth factor (TGF)- $\mathrm{b}^{22}$-resulting in epithelial damage and inflammatory cytokine activation. The resultant tear film instability exacerbates ocular surface hyperosmolarity and compounds the vicious cycle. ${ }^{18,19}$

Cyclosporine A is a neutrally charged hydrophobic molecule with low aqueous solubility, which poses challenges in making a safe and effective ocular drug delivery system. ${ }^{23}$ Cyclosporine A reduces the underlying inflammation associated with DED that interferes with tear production. ${ }^{24,25}$ Initially, cyclosporine A ophthalmic solutions were formulated in oil-based solvents such as castor oil or corn oil; however, oils caused side effects such as blurred vision, burning, and stinging, and were poorly tolerated. ${ }^{23}$ Additionally, these oils provided low bioavailability of cyclosporine A to the ocular targets. ${ }^{26,27}$ The limitations of oil-based cyclosporine A formulations lead to a need for cyclosporine A formulations with improved tolerability and bioavailability.

This review covers the immunopathophysiology of DED as well as the mechanism of action of cyclosporine $\mathrm{A}$ and its role in modulating ocular inflammation, compares the current ophthalmic cyclosporine A formulations, and discusses the limitations and challenges of using cyclosporine A for the treatment of DED.

\section{Ocular Inflammation in the Pathogenesis of DED}

The chronic inflammation that accompanies DED involves the innate and adaptive immune response and progresses through four stages: initiation, amplification, recruitment and damage/re-initiation (Figure 1). ${ }^{15}$ Throughout the inflammatory response, immune cells release proinflammatory cytokines and chemokines, which recruit more immune cells and eventually results in a vicious cycle of inflammation that does not resolve (Table 1). ${ }^{18,20}$

During the initiation stage, ocular stress increases inflammatory cytokine expression and activates MAPKs, including c-Jun N-terminal kinase (JNK), extracellular signal-related kinase, and $\mathrm{p} 38 .{ }^{28} \mathrm{JNK}$ causes transcription of matrix metalloproteases (MMPs). ${ }^{29}$ Natural killer (NK) cells, macrophages, and dendritic cells are all involved in this phase. ${ }^{15,18}$ NK cells promote inflammation, which 


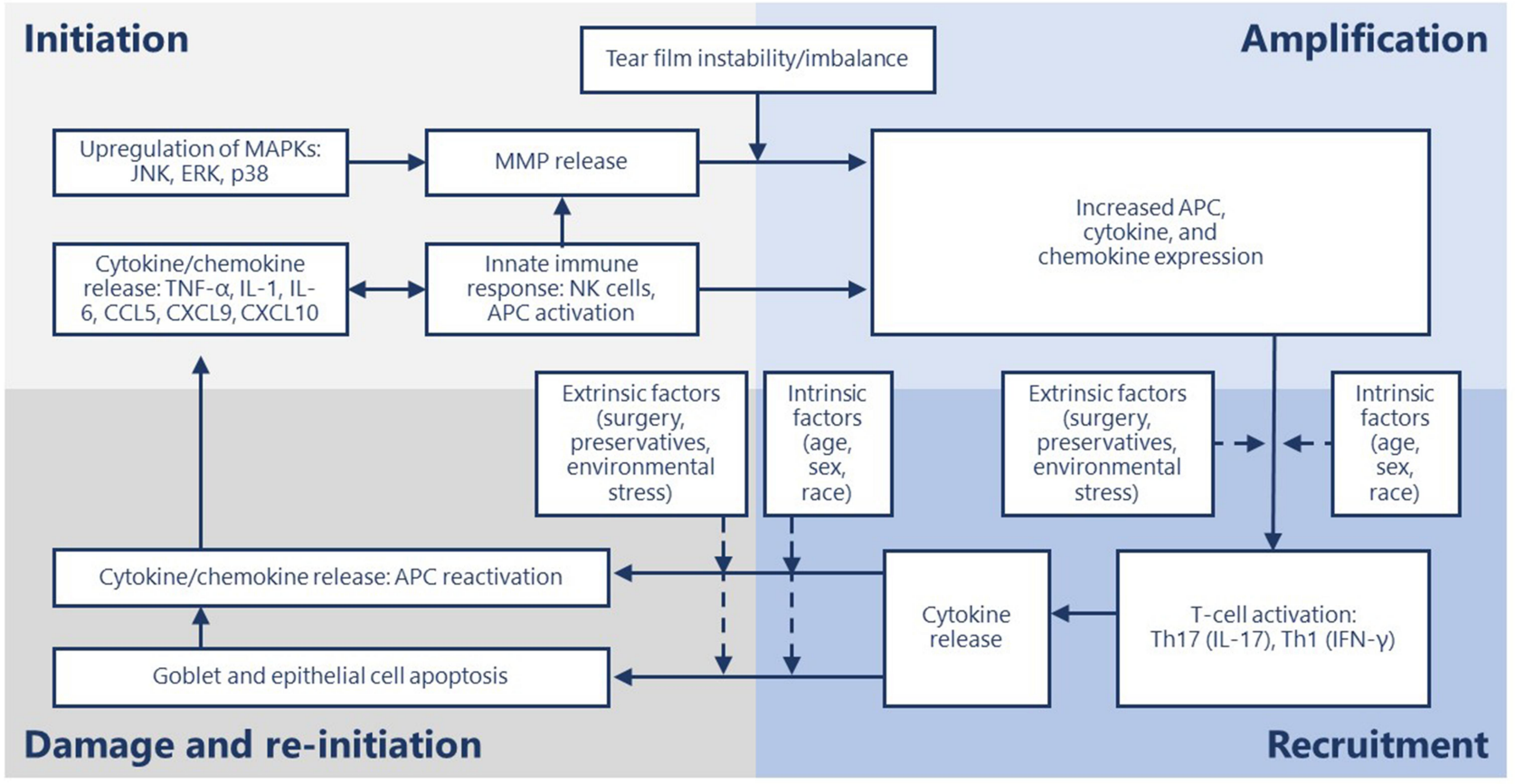

Figure I Stages of dry eye disease and primary effectors.

Abbreviations: APC, antigen-presenting cell; ERK, extracellular-signal-regulated kinase; CCL, C-C motif chemokine ligand; CXCL, C-X-C motif chemokine ligand; IFN, interferon; IL, interleukin; JNK, c-Jun N-terminal kinase; MAPK, mitogen-activated protein kinase; MMP, matrix metalloproteinases; NK, natural killer; Th, T-helper; TNF, tumor necrosis factor.

contributes to DED through a variety of mechanisms, including secreting interferon (IFN)- $\gamma$ and stimulating antigenpresenting cells (APCs). ${ }^{30}$ IFN- $\gamma$, a pro-inflammatory cytokine, upregulates a cluster of differentiation (CD) $4^{+}$ T cell-associated chemokines. ${ }^{31}$ Stimulated APCs expressing major histocompatibility complex class II (MHCII) promote differentiation and mediate the survival of $\mathrm{CD} 4{ }^{+} \mathrm{T}$ cells. ${ }^{32,33}$ In a mouse model of DED, NK cell depletion decreased interleukin (IL)-17A-producing $\mathrm{CD}^{+} \mathrm{T}$ cells in the ocular surface on day 5 following desiccant stress exposure and reduced expansion of two subsets of APCs,

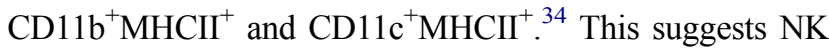
cells play a role in the inflammatory response of DED.

Macrophages can function as APCs to T cells and are reciprocally activated by $\mathrm{T}$ cells. ${ }^{35}$ Pro-inflammatory macrophages secrete $T$ cell attracting cytokines (IL- $1 \beta$, tumor necrosis factor- $\alpha$ [TNF- $\alpha]$, IL-12 and IL-23) as well as chemokines (C-X-C motif chemokine ligand [CXCL] 9 and CXCL10) that induce recruitment of T-helper (Th) 1 and Th17 inflammatory T cells which then may lead to tissue damage. ${ }^{36}$ In an experimental mouse model of DED, macrophage depletion reduced the expression of inflammatory mediators including IL-1 $\beta$, IL6, IL-17, and C-C motif chemokine ligand (CCL) 5 and CD4 T cells. ${ }^{37}$ CCL5 attracts $\mathrm{T}$ cells and has been found to be significantly increased in the tears of patients with DED. ${ }^{38}$ Similarly, IL-6 expression increases in patients with DED and is associated with the release of MMPs, decreased tear production, cell death, and Th17 cell differentiation. ${ }^{20,38,39}$

Dendritic cells act as the primary APC, and corneal dendritic cell density increases in DED. ${ }^{40}$ Dendritic cell maturation is induced by CCL19 and CCL21, two C-C motif chemokine receptor (CCR)7 ligands. ${ }^{41,42}$ These ligands also enhance the proliferation of T cells. ${ }^{41,42}$ CCL19 additionally up-regulates co-stimulatory molecules: CD86, CD80, and CD40 on dendritic cells. ${ }^{42}$ CCR7 expression increases during the maturation of dendritic cells. ${ }^{42}$ Increased receptor expression allows more ligand binding and facilitates interactions with $\mathrm{T}$ cells that also express CCR7 and bind CCL19 and CCL21. In a mouse model of DED, culture of $\mathrm{CCR} 7^{+} \mathrm{CD} 11 \mathrm{~b}^{+}$dendritic cells with IFN$\gamma^{-} \mathrm{IL}-17^{-} \mathrm{CD} 4^{+} \mathrm{T}$ cells stimulated $\mathrm{T}$ cell proliferation and T cell IL-17 expression. ${ }^{43}$ Thereby, CCR7 expression significantly contributes to the inflammatory response in DED. Blockade of CCR7 with a topical solution of rat anti-CCR7 impairs the induction of acute DED and the progression of acute to chronic DED as measured by corneal fluorescein staining. ${ }^{44}$ This results from reduced inflammatory cytokine expression at the ocular surface and retention of epithelial 
Table I Molecules Involved in the Inflammatory Response of Dry Eye Disease

\begin{tabular}{|c|c|}
\hline Molecule & Reference \\
\hline CCL2 & Nicolle P, Int J Mol Sci, $2018^{40}$ \\
\hline CCL3/MIPI $\alpha$ & $\begin{array}{l}\text { Schaumburg CS, J Immunol, 2011 }{ }^{37} \\
\text { Lam H, Am J Ophthalmol } 2009^{38}\end{array}$ \\
\hline CCL5/RANTES & $\begin{array}{l}\text { Schaumburg CS, J Immunol, 2011 } 37 \\
\text { Lam H, Am J Ophthalmol } 2009^{38}\end{array}$ \\
\hline CCLI9 & Marsland BJ, Immunity, $2005^{42}$ \\
\hline CCL20 & $\begin{array}{l}\text { Coursey TG, PLoS One, } 2013^{46} \\
\text { Dohlman TH, Invest Ophthalmol Vis Sci, } 2013^{47}\end{array}$ \\
\hline CCL2I & $\begin{array}{l}\text { Gollmer K, Blood, } 2009^{41} \\
\text { Marsland BJ, Immunity, } 2005^{42}\end{array}$ \\
\hline CCR2 & Nicolle P, Int J Mol Sci, $2018^{40}$ \\
\hline CCR6 & $\begin{array}{l}\text { Coursey TG, PLoS One, } 2013^{46} \\
\text { Dohlman TH, Invest Ophthalmol Vis Sci, } 2013^{47}\end{array}$ \\
\hline CCR7 & $\begin{array}{l}\text { Kodati S, Invest Ophthalmol Vis Sci, } 2014^{44} \\
\text { Marsland BJ, Immunity, } 2005^{42}\end{array}$ \\
\hline $\mathrm{CX} 3 \mathrm{CLI} /$ fractaline & Enriquez-de-Salamanca A, Mol Vis, $2010^{56}$ \\
\hline CXCL9 & $\begin{array}{l}\text { Coursey TG, J Immunol, 2014 } \\
\text { Arango Duque G, Front Immunol, 2014 }\end{array}$ \\
\hline CXCLIO & $\begin{array}{l}\text { Coursey TG, J Immunol, 2014 } \\
\text { Arango Duque G, Front Immunol, 2014 }\end{array}$ \\
\hline CXCLI2 & Nicolle P, Int J Mol Sci, $2018^{40}$ \\
\hline CXCR3 & Coursey TG, PLoS One, $2013^{46}$ \\
\hline CXCR4 & Nicolle P, Int J Mol Sci, $2018^{40}$ \\
\hline EGF & Lam H, Am J Ophthalmol $2009^{38}$ \\
\hline ICAM-I & Bang SP, PLoS One, $2019^{68}$ \\
\hline $\mathrm{IFN}-\gamma$ & 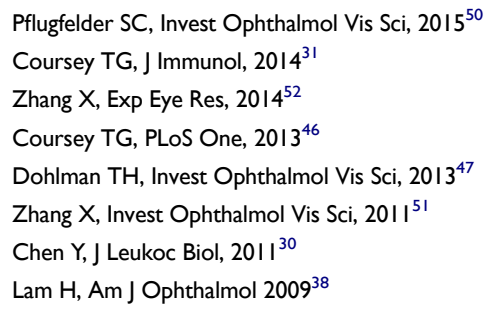 \\
\hline IL-I $\alpha$ & $\begin{array}{l}\text { Marko CK, Am J Pathol, 2013 } 3^{54} \\
\text { Lam H, Am J Ophthalmol } 2009^{38}\end{array}$ \\
\hline IL-I $\beta$ & $\begin{array}{l}\text { Bang SP, PLoS One, } 2019^{68} \\
\text { Arango Duque G, Front Immunol, } 2014^{36} \\
\text { Kodati S, Invest Ophthalmol Vis Sci, } 2014^{44} \\
\text { Marko CK, Am J Pathol, 2013 } \\
\text { Schaumburg CS, J Immunol, 2011 } \\
\text { Lam H, Am J Ophthalmol } 2009^{38}\end{array}$ \\
\hline IL-IRa & Enriquez-de-Salamanca A, Mol Vis, $2010^{56}$ \\
\hline
\end{tabular}

(Continued)
Table I (Continued)

\begin{tabular}{|c|c|}
\hline Molecule & Reference \\
\hline IL-2 & $\begin{array}{l}\text { Ames P, Clinical investigation, } 2015^{67} \\
\text { Matsuda S, Immunopharmacology, } 2000^{65} \\
\text { Matsuda S, J Biol Chem, } 1998^{66}\end{array}$ \\
\hline IL-4 & Matsuda S, Immunopharmacology, $2000^{65}$ \\
\hline IL-6 & $\begin{array}{l}\text { Bang SP, PLoS One, } 2019^{68} \\
\text { Kothari P, J Immunol, 2014 } \\
\text { Coursey TG, PLoS One, } 2013^{46} \\
\text { Dohlman TH, Invest Ophthalmol Vis Sci, } 2013^{47} \\
\text { Schaumburg CS, J Immunol, 201 I } \\
\text { Enriquez-de-Salamanca A, Mol Vis, } 2010^{56} \\
\text { Lam H, Am J Ophthalmol } 2009^{38}\end{array}$ \\
\hline IL-8/CXCL8 & $\begin{array}{l}\text { Enriquez-de-Salamanca A, Mol Vis, } 2010^{56} \\
\text { Lam H, Am J Ophthalmol } 2009^{38}\end{array}$ \\
\hline IL-10 & Lam H, Am J Ophthalmol $2009^{38}$ \\
\hline IL-12 & Arango Duque G, Front Immunol, $2014^{36}$ \\
\hline IL-13 & $\begin{array}{l}\text { Zhang X, Exp Eye Res, } 2014^{52} \\
\text { Coursey TG, PLoS One, } 2013^{46}\end{array}$ \\
\hline IL-17 & $\begin{array}{l}\text { Ji YW, Invest Ophthalmol Vis Sci, } 2014^{43} \\
\text { Kodati S, Invest Ophthalmol Vis Sci, } 2014^{44} \\
\text { Coursey TG, PLoS One, } 2013^{46} \\
\text { Dohlman TH, Invest Ophthalmol Vis Sci, } 2013^{47} \\
\text { Zhang X, PLoS One, } 2012^{34} \\
\text { Schaumburg CS, J Immunol, } 2011^{37} \\
\text { Chauhan SK, J Immunol, } 2009^{48}\end{array}$ \\
\hline IL-23 & $\begin{array}{l}\text { Arango Duque G, Front Immunol, } 2014^{36} \\
\text { Dohlman TH, Invest Ophthalmol Vis Sci, } 2013^{47}\end{array}$ \\
\hline MMP-I & Li DQ, Invest Ophthalmol Vis Sci, $2004^{29}$ \\
\hline MMP-3 & $\begin{array}{l}\text { Kodati S, Invest Ophthalmol Vis Sci, } 2014^{44} \\
\text { Coursey TG, PLoS One, } 2013^{46} \\
\text { Dohlman TH, Invest Ophthalmol Vis Sci, } 2013^{47}\end{array}$ \\
\hline MMP-9 & $\begin{array}{l}\text { Kothari P, J Immunol, 2014 } \\
\text { Coursey TG, PLoS One, } 2013^{46}\end{array}$ \\
\hline MMP-13 & Li DQ, Invest Ophthalmol Vis Sci, $2004^{29}$ \\
\hline NFKB & Du, J Immunol, $2009^{24}$ \\
\hline TGF- $\beta 2$ & Contreras-Ruiz L, PLoS One, $2015^{22}$ \\
\hline TNF- $\alpha$ & $\begin{array}{l}\text { Bang SP, PLoS One, } 2019^{68} \\
\text { Arango Duque G, Front Immunol, } 2014^{36} \\
\text { Kodati S, Invest Ophthalmol Vis Sci, } 2014^{44} \\
\text { Marko CK, Am J Pathol, } 2013^{54}\end{array}$ \\
\hline VCAM-I & Bang SP, PLoS One, $2019^{68}$ \\
\hline
\end{tabular}

Abbreviations: $\mathrm{CCL}, \mathrm{C}-\mathrm{C}$ motif chemokine ligand; $\mathrm{CCR}, \mathrm{C}-\mathrm{C}$ motif chemokine receptor; CXCL, C-X-C motif chemokine ligand; CXCR, C-X-C motif chemokine receptor; EGF, epidermal growth factor; ICAM, intercellular adhesion molecule; IFN, interferon; IL, interleukin; IL-IRa, interleukin I receptor antagonist; MIP, macrophage inflammatory protein; MMP, matrix metalloprotease; NFKB, nuclear factor kappa B; RANTES, regulated upon activation normal T cell expressed and secreted; TGF, transforming growth factor; TNF, tumor necrosis factor; VCAM, vascular cell adhesion molecule. 
cell integrity due to decreased expression of MMP-3, TNF- $\alpha$, IL-1 $\beta$ and Th17 cell secreted IL-17 after CCR7 blockade. ${ }^{44}$ In an in vivo study of cyclosporine A treated dendritic cells, CCR7 expression was inhibited while maintaining normal expression of CCR1, CCR2, and CCR5 antibodies-resulting in decreased expression of inflammatory cytokines. ${ }^{45}$ Subsequently, cyclosporine A actively counters the inflammatory response through inhibition of CCR7, disturbance of dendritic cell migration, and interaction with $\mathrm{T}$ cells - modulating the adaptive immune response. ${ }^{45}$

The initiation phase transitions to the amplification stage as pro-inflammatory cytokine expression and T-cellattracting chemokine expression increase APC activity and production of $\mathrm{CD}^{+}$T-cell subsets, resulting in amplification of the immune response. ${ }^{15}$ The resultant cytokine, chemokine, and immune cell presence drive the inflammatory response to the next stage.

During the recruitment stage, activated T-cells migrate to the conjunctival stroma where they reactivate resident APCs, and the $\mathrm{T}$ cells are recruited to the ocular surface. ${ }^{15}$ Desiccating stress increases the number of $\mathrm{CD} 4^{+} \mathrm{CCR} 6^{+} \mathrm{IL}-17^{+}$and $\mathrm{CD} 4^{+} \mathrm{C}-\mathrm{X}-\mathrm{C}$ motif chemokine receptor (CXCR) $3^{+} \mathrm{IFN}-\gamma^{+}$Th17 and Th1 cells in an experimental mouse model of DED, respectively. ${ }^{46}$ Th17 expression of CCR 6 and Th1 expression of CXCR3 is necessary for the development of DED; mice that lack these receptors do not develop DED, and IL-6, IL-13, IL-17A, IFN- $\gamma$, MMP-3, and MMP-9 expression is inhibited. ${ }^{46}$ Additionally, the expression of CCL20 and CCR6 ligand at the ocular surface is also decreased in DED. ${ }^{47}$ Blocking CCL20 inhibits Th17 cell migration to the ocular surface and decreases IL-6, IL-23, MMP-3, TNF- $\alpha$, and IFN- $\gamma$ messenger (m)RNA expression in the conjunctiva. ${ }^{47}$ Th17 cells are resistant to $\mathrm{T}$ regulatory cell (Treg) functions and antagonistic to Treg activity. ${ }^{48}$ Blockade of IL-17, a cytokine produced by Th17 cells, restored Treg function in mice treated with anti-IL-17 antibody compared to control mice. ${ }^{48}$ Desiccating stress also increases expression of Th1-associated chemokines, CXCL9 and CXCL10, via NK-cell mediated IFN- $\gamma$ expression. ${ }^{31}$ Resultantly, Th1 and Th17 cytokines damage the ocular surface and reinitiate the inflammatory cycle.

Throughout the first three stages of the chronic inflammatory response, increased TNF- $\alpha$ and IFN- $\gamma$ expression cause epithelial cell apoptosis and goblet cell loss, respectively. ${ }^{49,50}$ Excessive loss of goblet cells and epithelial apoptosis may result in a loss of immunoregulatory mechanisms, allowing the immune response to be amplified. ${ }^{15}$ In a desiccating stress mouse model of DED, IFN- $\gamma$ knockout mice had less active caspase 3 and caspase 8, indicating decreased apoptosis. ${ }^{51}$ Similarly, topical neutralization of IFN- $\gamma$ with rat anti-mouse IFN- $\gamma$ IgG1 decreased desiccating stress-induced conjunctival goblet cell loss, reduced epithelial apoptosis, and increased IL-13 expression. ${ }^{52}$ Goblet cells provide essential immunoregulatory functions by secreting TGF that downregulates dendritic cell expression of MHC class II and co-stimulatory molecules CD80, CD86 and CD40. These actions help to maintain the immature and immunotolerant state of the dendritic cell, which prevents $\mathrm{T}$ cell activation. ${ }^{22}$ Further evidence of the immunoregulatory role of goblet cells is seen in a goblet cell-deficient and SAM-pointed domain epithelial-specific transcription factor (Spdef)-null (sterile $\alpha$ motif pointed domain epithelialspecific transcription factor) mouse model, where findings mimicking DED in human patients was seen with increased macrophages and $\mathrm{CD} 11 \mathrm{~b}^{+} \mathrm{CD} 11 \mathrm{c}^{+}$dendritic cells ${ }^{53}$ as well as increased expression of proinflammatory IL- $1 \alpha$, IL- $1 \beta$, TNF$\alpha{ }^{54} \mathrm{An}$ increase in macrophages and dendritic cells leads to the recruitment of $\mathrm{T}$ cells and supports the continued release of inflammatory mediators as well as tissue damage.

Numerous cytokines and chemokines have altered expression in DED and contribute to the severity of symptoms. In a cohort of patients with DED, CCL2, CCR2, and CXCR4 mRNA levels significantly increased, while CXCL12 levels trended towards an increase. ${ }^{40}$ All these molecules modulate nociceptive signals and drive nerve pain. ${ }^{40,55}$ Concentrations of IL-8 (CXCL8), and macrophage inflammatory protein (MIP)-1 $\alpha$ (CCL3) were significantly increased in the tears of patients with DED, while epidermal growth factor (EGF) concentrations were significantly decreased. ${ }^{38}$ The severity of irritation symptoms positively correlated with IL- 6 and IL-8 concentrations, and Schirmer scores positively correlated with EGF and inversely correlated with IL-10, IL-8, MIP-1 $\alpha$, IL-1 $\alpha$, IL-1 $\beta$, IL-6, IL-1Ra, fractalkine (CX3CL1), IP-10 (CXCL10) and vascular endothelial growth factor concentrations. ${ }^{38,56}$ EGF negatively correlated with corneal fluorescein staining and conjunctival lissamine green staining, but IFN- $\gamma$, IL-8, MIP- $1 \alpha$, IL- $1 \alpha$, IL- $1 \beta$ and IL- 6 concentrations positively correlated with these scores. ${ }^{38,56}$

\section{Mechanism of Action of Cyclosporine A}

Cyclosporine A was isolated from the fungus Tolypocladium inflatum. ${ }^{57}$ The immunosuppressive activity of cyclosporine was discovered in 1976, leading to immunological tests and investigations into its structure 
and synthesis. ${ }^{58}$ Cyclosporine A was the first immunosuppressive drug that allowed selective immunoregulation of $\mathrm{T}$ cells without excessive toxicity and was used in routine organ transplantation to counter graft rejection. ${ }^{59}$

Topical cyclosporine A was developed to increase tear production in patients with DED who are refractory to conservative treatments such as ocular lubricants and lid hygiene, and its efficacy is well established. ${ }^{60,61}$ TFOS DEWS II recommends a stepwise approach to DED treatment, starting with education, dietary modification, lid hygiene, lubricating eye drops, and environmental modifications. ${ }^{5,61}$ If patients with DED are not adequately treated with ocular lubricants or lid hygiene, nonpharmacologic treatment can be used along with prescription medications such as topical cyclosporine A. ${ }^{61,62}$ However, because of the increasing awareness of the chronic and progressive nature of DED, cyclosporine $\mathrm{A}$ is also used for less severe DED in clinical practice. ${ }^{3}$

Cyclosporine $\mathrm{A}$ is a calcineurin inhibitor that exerts immunomodulatory effects by blocking $\mathrm{T}$ cell infiltration, activation, and the subsequent release of inflammatory cytokines. ${ }^{25,63,64}$ It enters the cytoplasm of $\mathrm{T}$ cells, binds to cyclophilin, and forms a cyclosporine $\mathrm{A} /$ cyclophilin complex that prevents calcineurin-mediated dephosphorylation of nuclear factor of activated $\mathrm{T}$ cells and the transcription of cytokine genes, including those of IL-2 and IL-4. ${ }^{65}$ Cyclosporine A additionally inhibits p38 activation and JNK activation, which lead to IL-2 production. ${ }^{66}$ The subsequent reduction in IL-2 levels further reduces the function of effector T cells. ${ }^{67}$

The action of cyclosporine A on T cells is the primary mechanism for DED symptom improvement; however, its effects may extend beyond $\mathrm{T}$ cell modulation. Twice-daily treatment for 2 weeks with cyclosporine A decreased expression of proinflammatory cytokines and chemokines IL-1 $\beta$, TNF- $\alpha$, IL-6, intercellular adhesion molecule 1 , and vascular cell adhesion molecule 1 in a murine model of benzalkonium chloride-induced DED ${ }^{68}$ Outside of DED, cyclosporine A affects cytokine expression and MHC expression. In an experimental rat model of autoimmune uveitis, cyclosporine A decreased levels of IL-1, IL-6, and TNF- $\alpha$ relative to the uveitis-induced placebo group. ${ }^{69}$

Moreover, cyclosporine A protects human conjunctival epithelial cells via its anti-apoptotic action, as well as improves conjunctival goblet cell density and corneal surface integrity via its immunomodulatory activities. ${ }^{25,61}$ Cyclosporine A blocks mitochondrial permeability transition pore opening in mitochondria, Fas/Fas ligand upregulation, and caspase activation, ${ }^{25}$ which are considered important aspects of its therapeutic efficacy for ocular inflammation in DED (Figure 2). ${ }^{25}$ The reduction in T cell recruitment and activation by cyclosporine A decreases IFN- $\gamma$ expression, which has been linked to epithelial cell and goblet cell apoptosis. ${ }^{50,70}$

\section{Cyclosporine A for the Treatment of Surgically Induced Dry Eye}

Surgical intervention is sometimes required to address ophthalmic diseases. ${ }^{6,13,61}$ Glaucoma, a major cause of blindness, is often treated with topical medications, but when medications are ineffective or contraindicated, surgery may be necessary. ${ }^{13}$ Visually significant cataracts may also require surgical removal. ${ }^{71}$ These surgical interventions may cause nerve damage or inflammation resulting in symptoms that mimic DED. Moreover, the type of equipment used during surgery can influence the development of dry eye symptoms and the necessity for postoperative dry eye treatment. ${ }^{72}$ New confocal microscopic evidence from cataract surgeries demonstrates surgical insult to the first eye creates corneal nerve sub-basal changes in both eyes, which may compromise the lacrimal functional unit. ${ }^{10}$

Cyclosporine A provides additional treatment options for patients with surgically induced dry eye. In a study of DED, dry eye symptoms increased at 1 month following laser-assisted in-situ keratomileusis (LASIK), but the use of topical cyclosporine A $0.05 \%$ emulsion improved post-LASIK dry-eye symptoms for up to 1 year, returning symptoms to preoperative baseline levels. ${ }^{73}$ Similarly, in a study of patients with dry eye following cataract surgery, dry eye symptoms improved from baseline after 3 months of twice-daily treatment with cyclosporine A. ${ }^{14}$ These findings are supported by an in vivo confocal microscopy study in patients with DED, in which twice-daily cyclosporine $0.05 \%$ ophthalmic emulsion administration increased intermediate epithelial cell density and decreased the morphologic markers of inflammation and nerve damage. ${ }^{74}$

\section{Cyclosporine A for the Treatment of Dry Eye Associated Comorbidities}

Chronic DED can often result in mechanical stress on the ocular surface-leading to continuous erosion and damage to corneal and conjunctival tissue. ${ }^{75}$ In a case series of 
A

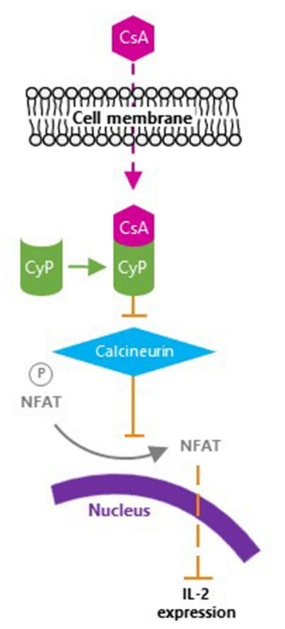

B

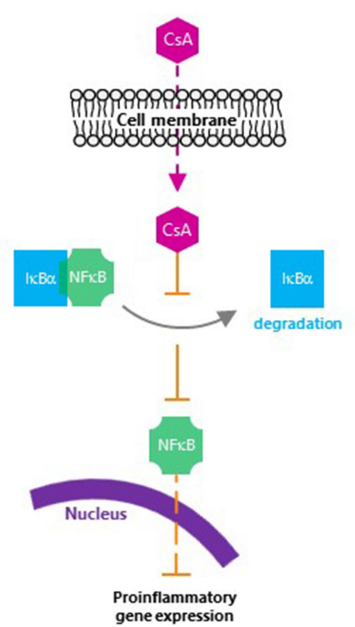

C

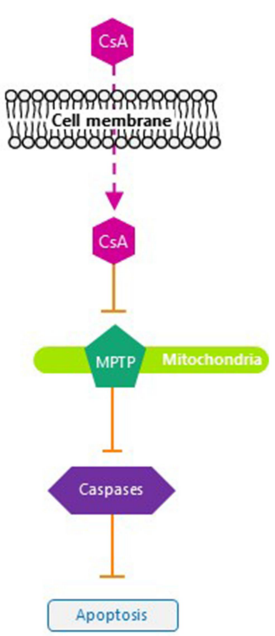

D

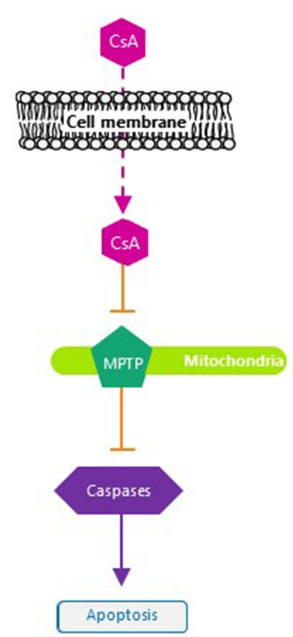

Figure 2 Mechanism of action of cyclosporine A. (A) Inactivates T cells. (B) Inhibits the release of inflammatory cytokines. (C) Prevents apoptosis of conjunctival epithelial cells. (D) Induces apoptosis of activated T cells.

Abbreviations: CsA, cyclosporine A; CyP, cyclophilin; І $\mathrm{K} ß \alpha$, nuclear factor of $\mathrm{\kappa}$ light polypeptide gene enhancer in B-cell inhibitor, alpha; IL-2, interleukin 2; MPTP, mitochondrial permeability transition pore; NFAT, nuclear factor of activated T cells; NFkB, nuclear factor of kappa B; P, phosphorylated.

patients with recurrent corneal erosions and refractory persistent epithelial defects, treatment with cyclosporine A $0.05 \%$ improved tear film stability, reduced recurrent corneal erosions, and completely healed areas of previous epithelial loss. ${ }^{75}$ Moreover, the reduction in recurrent corneal erosions paralleled improvements observed in DED signs and symptoms, indicating the decrease in ocular inflammation by cyclosporine A helped reduce mechanical stressors on the eye and improved epithelial integrity. ${ }^{75}$ Notably, in a recent review of ophthalmic medications with antiviral properties, the use of cyclosporine A for the potential treatment of coronavirus disease 2019induced conjunctivitis was suggested based on its shown antiviral activity against hepatitis $\mathrm{C}$ virus, flavivirus, and influenza. ${ }^{76}$ Although treatment for coronavirus-induced conjunctivitis with cyclosporine A is not known, patients with DED experiencing secondary viral infections affecting the ocular surface may benefit from cyclosporine A treatment.

\section{Comparing Ophthalmic Cyclosporine A Formulations}

Cyclosporine A has traditionally been formulated as an oilbased preparation due to its high lipophilicity and poor water solubility. ${ }^{23,67}$ However, oil-based solutions often have poor tolerability and low bioavailability. ${ }^{67}$ Due to the lipophilic nature of cyclosporine $\mathrm{A}$, it has a greater affinity for an oil-based vehicle than for the target tissues.
Therefore, aqueous delivery systems aim to increase cyclosporine A bioavailability and reduce adverse reactions. ${ }^{67}$

An ophthalmic emulsion of $0.05 \%$ cyclosporine A (Restasis ${ }^{\circledR}$; Allergan, Inc., Irvine, CA, USA) was the first topical cyclosporine A approved by the US Food and Drug Administration (FDA) in 2003 to increase tear production in patients whose tear production is presumed to be suppressed due to ocular inflammation associated with KCS (Table 2). ${ }^{23,60,61}$ It is a preservative-free anionic oilin-water formulation comprising castor oil with polysorbate 80 and carbomer copolymer acting as an emulsifying and stabilizing agent, respectively. ${ }^{23}$ In two multicenter, randomized, phase 3 trials, twice-daily administration of cyclosporine A $0.05 \%$ emulsion for 6 months significantly improved corneal staining and anesthetized Schirmer's tear test values from baseline compared with vehicle $(P \leq 0.05){ }^{77}$ Conjunctival staining in temporal and nasal conjunctival zones improved significantly from baseline in both cyclosporine A $0.05 \%$ emulsion and vehicle groups, but there was no significant difference between cyclosporine $\mathrm{A} \quad 0.05 \%$ emulsion and vehicle. ${ }^{77}$ Cyclosporine A $0.05 \%$ emulsion significantly $(P<0.001)$ improved tear film breakup time in patients with DED at month 6 in a phase 4 trial. $^{78}$ Approximately $43 \%$ of treated patients experienced adverse events (AEs), the most frequent being instillation site reactions including burning and pain. ${ }^{78}$

A cationic nanoemulsion of cyclosporine A (Ikervis ${ }^{\circledR}$; Santen SAS, Evry, France) (Table 2) was approved by the 
Table 2 Comparison of Approved Formulations of Cyclosporine A

\begin{tabular}{|c|c|c|c|c|}
\hline Name & Formulation & Composition & Advantages & Limitations \\
\hline Restasis $^{\circledR}$ & Emulsion & $\begin{array}{l}\text { Anionic oil in water } \\
\text { emulsion }^{60,77,78}\end{array}$ & $\begin{array}{l}\text { - At } 6 \text { months, corneal staining, Schirmer's } \\
\text { score, tear breakup time and subjective } \\
\text { patient symptoms improved vs } \\
\text { vehicle }^{77,78} \\
\text { - Disperses easily over the ocular surface }\end{array}$ & $\begin{array}{l}\text { - Low bioavailability of CsA to the ocular } \\
\text { surface }^{26} \\
\text { - Patients frequently reported discom- } \\
\text { fort on instillation }{ }^{78}\end{array}$ \\
\hline |kervis $^{\circledR}$ & Emulsion & $\begin{array}{l}\text { Cationic emulsion } \\
0.1 \%^{19,79,80}\end{array}$ & $\begin{array}{l}\text { - At } 6 \text { months, global symptom and corneal } \\
\text { staining scores had improved from } \\
\text { baseline }{ }^{19} \\
\text { - Greater bioavailability of CsA to ocular } \\
\text { tissues vs anionic emulsion }{ }^{23} \\
\text { - Administered once-daily }\end{array}$ & $\begin{array}{l}\text { - Low bioavailability of CsA to ocular } \\
\text { tissues }{ }^{26} \\
\text { - No significant change in corneal stain- } \\
\text { ing scores of number of patients } \\
\text { achieving improved OSDI scores vs } \\
\text { vehicle } \\
\text { - High patient dissatisfaction and reports } \\
\text { of ocular discomfort }^{19}\end{array}$ \\
\hline CEQUA $^{\mathrm{TM}}$ & $\begin{array}{l}\text { Aqueous } \\
\text { nanomicellar } \\
\text { solution }\end{array}$ & $\begin{array}{l}\text { OTX-I0I } 0.09 \% \\
\text { cyclosporine } \mathrm{A} \text {, } \\
\text { aqueous nanomicellar } \\
\text { solution }^{81,84,87}\end{array}$ & $\begin{array}{l}\text { - Corneal staining scores improved at } 4 \\
\text { weeks with continued improvement for } \\
\text { the duration of the study }{ }^{84,87} \\
\text { - Conjunctival staining scores improved at } \\
6 \text { weeks vs vehicle with continued } \\
\text { improvement throughout study }{ }^{84,87} \\
\text { - At } 3 \text { months, Schirmer's scores improved } \\
\text { vs vehicle }\end{array}$ & $\begin{array}{l}\text { - Efficacy in patients with severe KCS has } \\
\text { not yet been determined }\end{array}$ \\
\hline
\end{tabular}

Notes: Adapted with permission from Dove Medical Press Ltd. Jerkins GW, Pattar GR, Kannarr SR. A Review of Topical Cyclosporine A Formulations-A Disease-Modifying Agent for Keratoconjunctivitis Sicca. Clin Ophthalmol. 2020;14:48I-489. ${ }^{100}$

Abbreviations: CsA, cyclosporine A; KCS, keratoconjunctivitis sicca; OSDI, ocular surface disease index.

European Medical Agency in 2015 for patients with severe keratitis that has not improved with artificial tears. ${ }^{23,79}$ In a phase 3 study, the cationic emulsion of cyclosporine A significantly improved corneal staining over 6 months compared with vehicle $(\mathrm{P}=0.037) .{ }^{80}$ However, in the combined outcome of improvement of $\geq 2$ grades in corneal staining and improvement of $\geq 30 \%$ in ocular surface disease index, the cationic emulsion was not significantly different than vehicle. ${ }^{80}$ Furthermore, a greater number of patients in the emulsion group vs vehicle group experienced instillation discomfort $(29.2 \%$ vs $8.9 \%)$ and $10 \%$ in the cationic emulsion group discontinued the study. ${ }^{80}$

OTX-101 0.09\% (CEQUA ${ }^{\mathrm{TM}}$; cyclosporine A 0.09\%; Sun Pharmaceutical Industries, Inc., Princeton, NJ, USA) is a clear, aqueous nanomicellar formulation approved by the FDA in 2018 to increase tear production in patients with KCS (Table 2). ${ }^{81,82}$ Nanomicelles are amphiphilic molecules that self-assemble into typical nanometer-sized supramolecular aggregates above the critical micelle concentration in an aqueous medium. Hydrophobic interactions of core-forming units drive the micelle formation with a water-insoluble or hydrophobic core and an outer water-soluble or hydrophilic shell. ${ }^{82}$ Thus, the nanomicelles encapsulate hydrophobic cyclosporine A within their hydrophilic cores, and that, in turn, favors dispersion and solubility of cyclosporine A into the precorneal tear film. $^{82,83}$ The small size of nanomicelles $(10-80 \mathrm{~nm}$; average of $22 \mathrm{~nm}$ ) may also allow diffusion through scleral aqueous pores $(20-80 \mathrm{~nm}$ in size $){ }^{83}$

Phase $2 b / 3$ and 3 clinical studies showed twice-daily administration of OTX-101 0.09\% was superior to vehicle in increasing tear production and improving ocular signs, including conjunctival and corneal staining in patients with DED as early as 4 weeks. ${ }^{84-87}$ In a pooled analysis of phase $2 \mathrm{~b} / 3$ and 3 trials, OTX-101 $0.09 \%$ significantly improved total corneal staining on day 28 vs vehicle $(P=$ $0.0008),{ }^{85}$ and significantly reduced total conjunctival staining from baseline vs vehicle $(P=0.0316)$ was seen on day $28 .^{86}$ This reduction in conjunctival and corneal staining suggests an improvement in ocular surface integrity and DED pathology, as indicated in previous studies involving a different cyclosporine A formulation. ${ }^{77}$ By day 84, significantly more patients had an increase in Schirmer's score of $\geq 10 \mathrm{~mm}$ from baseline in the OTX- 
$1010.09 \%$ group vs vehicle (16.6\% vs $9.0 \%$, respectively, $\mathrm{P}<0.0001){ }^{88}$

The majority of enrolled patients on OTX-101 $0.09 \%$ completed phase $2 \mathrm{~b} / 3$ and 3 studies $(93 \%)$, with $\leq 2.9 \%$ withdrawing due to AEs. ${ }^{84,86}$ During the 3-month treatment period, instillation site pain was the most frequent $\mathrm{AE}(15.1 \%$ and $24.2 \%$ of patients in the phase $2 \mathrm{~b} / 3$ and phase 3 studies, respectively). ${ }^{84,87}$ Most treatment-emergent AEs (TEAEs) were mild or moderate and resolved without treatment. ${ }^{84}$ There were no serious TEAEs. ${ }^{84,86,87}$ In patients receiving OTX-101 $0.09 \%, 3.3 \%$ and $3.5 \%$ of patients withdrew from treatment due to treatment-emergent AEs in the phase $2 \mathrm{~b} / 3$ and phase 3 studies, respectively. ${ }^{84,87}$

A preclinical study in New Zealand white rabbits demonstrated a higher cyclosporine A concentration after a single dosing of OTX-101 $0.05 \%$ compared with the cyclosporine A $0.05 \%$ emulsion in most ocular tissue samples, including the cornea (2.18-fold) and superior bulbar conjunctiva (1.76-fold) with minimal systemic exposure. ${ }^{89}$ There was a dose-related increase in cyclosporine A with repeat dosing of OTX-101 0.05\%, which also resulted in higher concentrations of cyclosporine $\mathrm{A}$ in ocular tissues and aqueous humor than in the cyclosporine A $0.05 \%$ emulsion. $^{89}$

\section{Differences in Delivery Vehicles}

Cyclosporine A $0.05 \%$ ophthalmic emulsion is formulated in a homogenous emulsion of glycerin $(2.2 \%)$, castor oil $(1.25 \%)$, polysorbate $80(1.00 \%)$, carbomer copolymer type A (0.05\%), purified water (to $100 \%$ ) and sodium hydroxide for $\mathrm{pH}$ adjustment. ${ }^{60,67}$ Other common formulation strengths include $0.5 \%, 1 \%$, and $2 \% .{ }^{67}$ Injectable cyclosporine $\mathrm{A}$ in artificial tears is often used in lowerdose formulations $(0.5 \%$ and $1 \%)$, while higher-dose $(2 \%)$ formulations are compounded utilizing the oral solution of cyclosporine $\mathrm{A}$ in sterile corn or olive oil. ${ }^{67}$ Tolerability of injectable cyclosporine $\mathrm{A}$ is poor due to the high alcohol content-limiting its use to lower-dose formulations. ${ }^{67}$ However, oil-based deliveries such as oily vehicles or oilin-water emulsions may pose similar challenges to tolerability such as irritation and blurred vision. ${ }^{27}$

Cyclosporine A ophthalmic formulations containing lipids are prepared as emulsions, which can be classified as either macroemulsions, nanoemulsions, or microemulsions based on lipid droplet size. ${ }^{61}$ Smaller droplet size minimizes adverse effects such as discomfort or blurring upon instillation. ${ }^{61}$ Consequently, in patients with the aqueous tear-deficient form of dry eye and an increased lipid tear film, lipid-based formulations may cause increased discomfort when applied.

Aqueous vehicle preparations were developed with different variations of nanoparticle-based suspensions and/or micellar or nanomicellar solutions (eg, OTX-101). ${ }^{23,90}$ Preclinical studies support the superior tolerability and greater bioavailability of cyclosporine A with micellar solutions vs oil-based emulsions; the bioavailability exceeds that of cyclosporine $0.05 \%$ ophthalmic emulsion and cationic emulsions. ${ }^{90}$ Moreover, some cationic emulsions potentially induce corneal epitheliopathy, disrupt corneal barrier function, and increase metabolic stress in rabbit corneas. ${ }^{91}$ In contrast, aqueous vehicles can deliver therapeutically active cyclosporine A levels to tissues of the anterior and posterior ocular segments. ${ }^{67}$ Outcomes from this study also suggest higher bioavailability and lower elimination rates compared with cyclosporine $0.05 \%$ ophthalmic emulsion. ${ }^{67}$

Additionally, buffering agents used in cyclosporine A ophthalmic formulations are important to patient comfort and safety as well as pharmacologic activity. Buffers are not only necessary to stabilize a formulation's $\mathrm{pH}$ for optimal solubility, tolerability, and activity but should also simulate the natural system of the tear film. ${ }^{92}$ To date, the most commonly used buffers in ophthalmic formulations include citrate, phosphate, Tris- $\mathrm{HCl}$, and borate. ${ }^{92}$ Although AEs with citrate, Tris- $\mathrm{HCl}$, and borate are not commonly reported in the literature, phosphate buffers may induce corneal calcification. ${ }^{92}$ In a recent study evaluating buffer-induced cytotoxicity in a human corneal epithelial and conjunctival cell model, both citrate and phosphate buffers resulted in significant cytotoxic effects at high concentration levels and long incubation times in a cell model of ocular epithelial tissue. ${ }^{92}$ For currently approved cyclosporine A formulations, sodium hydroxide and sodium phosphate monobasic dihydrate are used as buffering agents for cyclosporine $0.09 \%$ ophthalmic solution (OTX$101),{ }^{81}$ while sodium hydroxide is the sole buffering agent in both cyclosporine A $0.05 \%$ ophthalmic emulsion and cyclosporine A $0.1 \%$ ophthalmic emulsion. ${ }^{60,79}$

\section{Alternative Current Pharmacologic Treatments for DED}

According to TFOS DEWS II, the management of DED should be performed in an individualized, step-wise approach. ${ }^{61}$ Although ocular lubricants are commonly used in the management of early DED, they fail to address the underlying causes of DED and only deliver palliative care. ${ }^{61}$ Consequently, many patients who are refractory to 
over-the-counter lubricants turn to prescription medications including limited-duration topical corticosteroids, topical antibiotics (eg, tetracyclines), lymphocyte function-associated (LFA) antigen-1 antagonist, topical secretagogues, and cyclosporine. ${ }^{61}$ While topical corticosteroids demonstrate effective interruption of the inflammatory and immune response cycle of DED, long-term use can present complications such as ocular hypertension and opportunistic infections. ${ }^{61,93}$ Tetracyclines are broad-spectrum antibiotics possessing anti-inflammatory properties that effectively treat disorders associated with DED; ${ }^{61}$ however, risks associated with long-term use of tetracyclines are unknown and long-term use could lead to potential antibiotic resistance. The topical secretagogue diquafosol tetrasodium is approved for the treatment of DED in Japan and South Korea, though in the US, it did not meet primary and secondary endpoints in phase 3 clinical trial and did not receive FDA approval. ${ }^{61,94}$ Lifitegrast (Xiidra $^{\circledR}$, Novartis, Basel, Switzerland), a 5\% ophthalmic solution of the LFA antigen-1 antagonist, is approved for the treatment of signs and symptoms of DED. ${ }^{95}$ Lifitegrast targets inflammation by inhibiting $\mathrm{T}$ cell recruitment, $\mathrm{T}$ cell activation, and subsequent cytokine release. ${ }^{96}$

\section{Limitations and Challenges of Cyclosporine A for the Treatment of Dry Eye Disease}

Ocular targets for drug delivery in DED include the cornea, conjunctiva, tear film, and lacrimal and meibomian glands. ${ }^{18}$ However, ocular barriers and dynamic mechanisms limit the bioavailability of topically administered drugs to $<5 \%$. ${ }^{97}$ Structures such as the corneal epithelium, stroma, and blood-aqueous barrier impede drug delivery. In addition, tear turnover rate, dilution into tears, blinking, and tear clearance shorten the exposure to topically administered drugs. Drug permeability into the conjunctiva is further limited by extensive vascular and lymphatic drainage. $^{97}$ Loss of drug volume can also occur due to gravity and nasolacrimal drainage. ${ }^{82}$

\section{Conclusions}

The complex and chronic nature of DED and its potential for progression require ongoing persistence with treatment. Topical cyclosporine A provides a broad-based approach to DED treatment by decreasing inflammation and improving ocular surface integrity with few systemic effects. In particular, cyclosporine A targets the cycle of chronic inflammation in DED through regulation of the various disease stages including initiation, amplification, recruitment and damage/re-initiation. Through immunomodulatory effects, topical cyclosporine A may prevent activation of conjunctival $\mathrm{T}$ cells, ${ }^{98}$ restore conjunctival goblet cell density, ${ }^{99}$ reduce transcription of inflammatory cytokines such as IL-2, ${ }^{67}$ and decrease epithelial cell apoptosis $^{25}$ - thereby, interrupting the ongoing immune reaction and cycle. New cyclosporine A formulations such as aqueous nanomicellar formulations address some of the delivery challenges with topical administration of cyclosporine A and may decrease the time to symptom relief, improve tolerability, and enhance patient persistence with therapy. Future treatment of dry eye will likely move towards the development of noninvasive sustained-release cyclosporine A formulations, providing patients with controlled, long-acting treatment.

\section{Acknowledgments}

Writing and editorial support for manuscript preparation were provided by Zehra Gundogan, VMD; and Shavonn Harper, PhD (AlphaBioCom, LLC, King of Prussia, PA); and funded by Sun Pharmaceutical Industries, Inc. (Princeton, NJ). All authors met the International Council of Medical Journal Editors criteria and received neither honoraria nor payment for authorship.

\section{Disclosure}

LMP reports research support from Lumenis and Olympic Ophthalmics, is a shareholder for Eyedetec and Visant, and reports consulting fees from Alcon; Allergan; Avellino; Azura; EyeVance; Novartis; Science Based Health; Sight Sciences; Sun Pharmaceutical Industries, Inc.; and TearLab. FSM reports equity from Ocular Science during the conduct of the study, received grants from Allergan, reports personal fees from Shire/Takeda outside the submitted work, and is a consultant for Sun Pharmaceutical Industries, Inc.; Novartis; and Allergan. PMK receives fees from Akorn; Alcon; Aldeyra; Allergan; Allysta; Aurinia; Azura; B+L; BioTissue; Blephex; Cambium; Dompe; Eyevance; Eyegate; ; Johnson \& Johnson; Kala; Mallinckrodt; Novaliq; Novartis; Oasis; Ocugen; Ocular Science; Oculus; OcuSoft; Olympic Ophthalmics; Regener-Eyes; Science Based Health; Sight Sciences; Sun Pharmaceutical Industries, Inc.; Surface; Tarsus; TearLab; and Vital Tears. The authors report no other conflicts of interest in this work. 


\section{References}

1. Farrand KF, Fridman M, Stillman IO, Schaumberg DA. Prevalence of diagnosed dry eye disease in the United States among adults aged 18 years and older. Am J Ophthalmol. 2017;182:90-98. doi:10.1016/j.ajo.2017.06.033

2. Stapleton F, Alves M, Bunya VY, et al. TFOS DEWS II epidemiology report. Ocul Surf. 2017;15(3):334-365. doi:10.1016/j. jtos.2017.05.003

3. de Oliveira RC, Wilson SE. Practical guidance for the use of cyclosporine ophthalmic solutions in the management of dry eye disease. Clin Ophthalmol. 2019;13:1115-1122. doi:10.2147/ OPTH.S184412

4. McDonald M, Patel DA, Keith MS, Snedecor SJ. Economic and humanistic burden of dry eye disease in Europe, North America, and Asia: a systematic literature review. Ocul Surf. 2016;14 (2):144-167. doi:10.1016/j.jtos.2015.11.002

5. Craig JP, Nichols KK, Akpek EK, et al. TFOS DEWS II definition and classification report. Ocul Surf. 2017;15(3):276-283. doi:10.1016/j.jtos.2017.05.008

6. Fahmy RM, Aldarwesh A. Correlation between dry eye and refractive error in Saudi young adults using noninvasive Keratograph 4. Indian $J$ Ophthalmol. 2018;66(5):653-656. doi:10.4103/ijo.IJO_1103_17

7. Nichols JJ, Ziegler C, Mitchell GL, Nichols KK. Self-reported dry eye disease across refractive modalities. Invest Ophthalmol Vis Sci. 2005;46(6):1911-1914. doi:10.1167/iovs.04-1294

8. Pisella PJ, Pouliquen P, Baudouin C. Prevalence of ocular symptoms and signs with preserved and preservative free glaucoma medication. Br J Ophthalmol. 2002;86(4):418-423. doi:10.1136/ bjo.86.4.418

9. Lopes NLV, Gracitelli CPB, Chalita MR, de Faria NVL. Ocular surface evaluation after the substitution of benzalkonium chloride preserved prostaglandin eye drops by a preservative-free prostaglandin analogue. Med Hypothesis Discov Innov Ophthalmol. 2019;8(1):52-56.

10. Giannaccare G, Bernabei F, Pellegrini M, et al. Bilateral morphometric analysis of corneal sub-basal nerve plexus in patients undergoing unilateral cataract surgery: a preliminary in vivo confocal microscopy study. $\mathrm{Br} J$ Ophthalmol. 2020. doi:10.1136/ bjophthalmol-2019-315449

11. He Y, Li J, Zhu J, Jie Y, Wang N, Wang J. The improvement of dry eye after cataract surgery by intraoperative using ophthalmic viscosurgical devices on the surface of cornea: the results of a consort-compliant randomized controlled trial. Medicine (Baltimore). 2017;96(50): e8940. doi:10.1097/MD.0000000000008940

12. Ishrat S, Nema N, Chandravanshi SCL. Incidence and pattern of dry eye after cataract surgery. Saudi J Ophthalmol. 2019;33 (1):34-40. doi:10.1016/j.sjopt.2018.10.009

13. Lee SY, Wong TT, Chua J, Boo C, Soh YF, Tong L. Effect of chronic anti-glaucoma medications and trabeculectomy on tear osmolarity. Eye (Lond). 2013;27(10):1142-1150. doi:10.1038/ eye.2013.144

14. Lee JH, Song IS, Kim KL, Yoon SY. Effectiveness and optical quality of topical $3.0 \%$ diquafosol versus $0.05 \%$ cyclosporine A in dry eye patients following cataract surgery. $J$ Ophthalmol. 2016;2016:8150757. doi:10.1155/2016/8150757

15. Periman LM, Perez VL, Saban DR, Lin MC, Neri P. The immunological basis of dry eye disease and current topical treatment options. J Ocul Pharmacol Ther. 2020;36(3):137-146. doi:10.1089/jop.2019.0060

16. Baudouin C, Messmer EM, Aragona P, et al. Revisiting the vicious circle of dry eye disease: a focus on the pathophysiology of meibomian gland dysfunction. Br J Ophthalmol. 2016;100 (3):300-306. doi:10.1136/bjophthalmol-2015-307415
17. Geerling G, Baudouin C, Aragona P, et al. Emerging strategies for the diagnosis and treatment of meibomian gland dysfunction: proceedings of the OCEAN group meeting. Ocul Surf. 2017;15 (2):179-192. doi:10.1016/j.jtos.2017.01.006

18. Bron AJ, de Paiva CS, Chauhan SK, et al. TFOS DEWS II pathophysiology report. Ocul Surf. 2017;15(3):438-510. doi:10.1016/j.jtos.2017.05.011.

19. Baudouin C, Irkec M, Messmer EM, et al. Clinical impact of inflammation in dry eye disease: proceedings of the ODISSEY group meeting. Acta Ophthalmol. 2018;96(2):111-119. doi:10.1111/ aos. 13436

20. Stern ME, Schaumburg CS, Pflugfelder SC. Dry eye as a mucosal autoimmune disease. Int Rev Immunol. 2013;32(1):19-41. doi:10.3109/08830185.2012.748052

21. Zhang X, Qu Y, He X, et al. Dry eye management: targeting the ocular surface microenvironment. Int J Mol Sci. 2017;18(7):1398. doi:10.3390/ijms 18071398

22. Contreras-Ruiz L, Masli S. Immunomodulatory cross-talk between conjunctival goblet cells and dendritic cells. PLoS One. 2015;10(3):e0120284. doi:10.1371/journal.pone.0120284

23. Lallemand F, Schmitt M, Bourges JL, Gurny R, Benita S, Garrigue JS. Cyclosporine A delivery to the eye: a comprehensive review of academic and industrial efforts. Eur J Pharm Biopharm. 2017;117:14-28. doi:10.1016/j.ejpb.2017.03.006

24. Du S, Hiramatsu N, Hayakawa K, et al. Suppression of NF-kappaB by cyclosporin a and tacrolimus (FK506) via induction of the C/EBP family: implication for unfolded protein response. J Immunol. 2009;182(11):7201-7211. doi:10.4049/ jimmunol.0801772

25. Gao J, Sana R, Calder V, et al. Mitochondrial permeability transition pore in inflammatory apoptosis of human conjunctival epithelial cells and T cells: effect of cyclosporin A. Invest Ophthalmol Vis Sci. 2013;54(7):4717-4733. doi:10.1167/iovs.13-11681

26. Cholkar K, Patel A, Vadlapudi AD, Mitra AK. Novel nanomicellar formulation approaches for anterior and posterior segment ocular drug delivery. Recent Pat Nanomed. 2012;2(2):82-95. doi:10.2174/1877912311202020082

27. Kuwano M, Ibuki H, Morikawa N, Ota A, Kawashima Y Cyclosporine A formulation affects its ocular distribution in rabbits. Pharm Res. 2002;19(1):108-111. doi:10.1023/A:1013671819604

28. Luo L, Li DQ, Doshi A, Farley W, Corrales RM, Pflugfelder SC. Experimental dry eye stimulates production of inflammatory cytokines and MMP-9 and activates MAPK signaling pathways on the ocular surface. Invest Ophthalmol Vis Sci. 2004;45 (12):4293-4301. doi:10.1167/iovs.03-1145

29. Li DQ, Chen Z, Song XJ, Luo L, Pflugfelder SC. Stimulation of matrix metalloproteinases by hyperosmolarity via a JNK pathway in human corneal epithelial cells. Invest Ophthalmol Vis Sci. 2004;45(12):4302-4311. doi:10.1167/iovs.04-0299

30. Chen Y, Chauhan SK, Saban DR, Sadrai Z, Okanobo A, Dana R. Interferon-gamma-secreting NK cells promote induction of dry eye disease. J Leukoc Biol. 2011;89(6):965-972. doi:10.1189/jlb.1110611

31. Coursey TG, Bohat R, Barbosa FL, Pflugfelder SC, de Paiva CS Desiccating stress-induced chemokine expression in the epithelium is dependent on upregulation of NKG2D/RAE-1 and release of IFN-gamma in experimental dry eye. J Immunol. 2014;193 (10):5264-5272. doi:10.4049/jimmunol.1400016

32. Brocker T. Survival of mature CD4 T lymphocytes is dependent on major histocompatibility complex class II-expressing dendritic cells. $J$ Exp Med. 1997;186(8):1223-1232. doi:10.1084/ jem.186.8.1223

33. Lemos MP, Fan L, Lo D, Laufer TM. CD8alpha+ and CD11b+ dendritic cell-restricted MHC class II controls Th1 CD4+ T cell immunity. J Immunol. 2003;171(10):5077-5084. doi:10.4049/ jimmunol.171.10.5077 
34. Zhang X, Volpe EA, Gandhi NB, et al. NK cells promote Th-17 mediated corneal barrier disruption in dry eye. PLoS One. 2012;7 (5):e36822. doi:10.1371/journal.pone.0036822

35. Zhou D, Chen YT, Chen F, et al. Critical involvement of macrophage infiltration in the development of Sjogren's syndromeassociated dry eye. Am J Pathol. 2012;181(3):753-760. doi:10.1016/j.ajpath.2012.05.014

36. Arango Duque G, Descoteaux A. Macrophage cytokines: involvement in immunity and infectious diseases. Front Immunol. 2014;5:491. doi:10.3389/fimmu.2014.00491

37. Schaumburg CS, Siemasko KF, De Paiva CS, et al. Ocular surface APCs are necessary for autoreactive T cell-mediated experimental autoimmune lacrimal keratoconjunctivitis. J Immunol. 2011;187 (7):3653-3662. doi:10.4049/jimmunol.1101442

38. Lam H, Bleiden L, de Paiva CS, Farley W, Stern ME, Pflugfelder SC. Tear cytokine profiles in dysfunctional tear syndrome. Am J Ophthalmol. 2009;147(2):198-205e191. doi:10.1016/j.ajo.2008.08.032

39. Kothari P, Pestana R, Mesraoua R, et al. IL-6-mediated induction of matrix metalloproteinase- 9 is modulated by JAK-dependent IL-10 expression in macrophages. $J$ Immunol. 2014;192 (1):349-357. doi:10.4049/jimmunol.1301906

40. Nicolle P, Liang H, Reboussin E, et al. Proinflammatory markers, chemokines, and enkephalin in patients suffering from dry eye disease. Int $J$ Mol Sci. 2018;19(4):1221. doi:10.3390/ijms19041221

41. Gollmer K, Asperti-Boursin F, Tanaka Y, et al. CCL21 mediates CD4+ T-cell costimulation via a DOCK2/Rac-dependent pathway. Blood. 2009;114(3):580-588. doi:10.1182/blood-200901-200923

42. Marsland BJ, Battig P, Bauer M, et al. CCL19 and CCL21 induce a potent proinflammatory differentiation program in licensed dendritic cells. Immunity. 2005;22(4):493-505. doi:10.1016/j. immuni.2005.02.010

43. Ji YW, Seo Y, Choi W, et al. Dry eye-induced CCR7+CD11b+ cell lymph node homing is induced by COX-2 activities. Invest Ophthalmol Vis Sci. 2014;55(10):6829-6838. doi:10.1167/ iovs.14-14744

44. Kodati S, Chauhan SK, Chen Y, et al. CCR7 is critical for the induction and maintenance of Th17 immunity in dry eye disease. Invest Ophthalmol Vis Sci. 2014;55(9):5871-5877. doi:10.1167/ iovs.14-14481

45. Chen T, Guo J, Yang M, et al. Cyclosporin A impairs dendritic cell migration by regulating chemokine receptor expression and inhibiting cyclooxygenase-2 expression. Blood. 2004;103 (2):413-421. doi:10.1182/blood-2003-07-2412

46. Coursey TG, Gandhi NB, Volpe EA, Pflugfelder SC, de Paiva CS. Chemokine receptors CCR6 and CXCR3 are necessary for CD4 $(+)$ T cell mediated ocular surface disease in experimental dry eye disease. PLoS One. 2013;8(11):e78508. doi:10.1371/journal. pone. 0078508

47. Dohlman TH, Chauhan SK, Kodati S, et al. The CCR6/CCL20 axis mediates Th17 cell migration to the ocular surface in dry eye disease. Invest Ophthalmol Vis Sci. 2013;54(6):4081-4091. doi:10.1167/iovs.12-11216

48. Chauhan SK, El Annan J, Ecoiffier T, et al. Autoimmunity in dry eye is due to resistance of Th17 to Treg suppression. J Immunol. 2009;182(3):1247-1252. doi:10.4049/jimmunol.182.3.1247

49. García-Posadas L, Contreras-Ruiz L, Soriano-Romaní L, Dartt DA, Diebold Y. Conjunctival goblet cell function: effect of contact lens wear and cytokines. Eye Contact Lens. 2016;42 (2):83-90. doi:10.1097/ICL.0000000000000158

50. Pflugfelder SC, De Paiva CS, Moore QL, et al. Aqueous tear deficiency increases conjunctival interferon-gamma (IFN-gamma) expression and goblet cell loss. Invest Ophthalmol Vis Sci. 2015;56(12):7545-7550. doi:10.1167/iovs.15-17627
51. Zhang X, Chen W, De Paiva CS, et al. Interferon-gamma exacerbates dry eye-induced apoptosis in conjunctiva through dual apoptotic pathways. Invest Ophthalmol Vis Sci. 2011;52 (9):6279-6285. doi:10.1167/iovs.10-7081

52. Zhang X, De Paiva CS, Su Z, Volpe EA, Li DQ, Pflugfelder SC. Topical interferon-gamma neutralization prevents conjunctival goblet cell loss in experimental murine dry eye. Exp Eye Res. 2014;118:117-124. doi:10.1016/j.exer.2013.11.011

53. Ko BY, Xiao Y, Barbosa FL, de Paiva CS, Pflugfelder SC. Goblet cell loss abrogates ocular surface immune tolerance. JCI Insight. 2018;3(3). doi:10.1172/jci.insight.98222

54. Marko CK, Menon BB, Chen G, Whitsett JA, Clevers H, Gipson IK. Spdef null mice lack conjunctival goblet cells and provide a model of dry eye. Am J Pathol. 2013;183(1):35-48. doi:10.1016/j. ajpath.2013.03.017

55. Li XQ, Zhang ZL, Tan WF, Sun XJ, Ma H. Down-regulation of CXCL12/CXCR4 expression alleviates ischemia-reperfusioninduced inflammatory pain via inhibiting glial TLR4 activation in the spinal cord. PLoS One. 2016;11(10): 0163807. doi:10.1371/journal.pone.0163807

56. Enriquez-de-Salamanca A, Castellanos E, Stern ME, et al. Tear cytokine and chemokine analysis and clinical correlations in evaporative-type dry eye disease. Mol Vis. 2010;16:862-873.

57. Bushley KE, Raja R, Jaiswal P, et al. The genome of tolypocladium inflatum: evolution, organization, and expression of the cyclosporin biosynthetic gene cluster. PLoS Genet. 2013;9(6): e1003496. doi:10.1371/journal.pgen.1003496

58. Borel JF, Feurer C, Magnee C, Stahelin H. Effects of the new anti-lymphocytic peptide cyclosporin A in animals. Immunology. 1977;32(6):1017-1025.

59. Haddad EM, McAlister VC, Renouf E, Malthaner R, Kjaer MS, Gluud LL. Cyclosporin versus tacrolimus for liver transplanted patients. Cochrane Database Syst Rev. 2006;4:Cd005161.

60. RESTASIS ${ }^{\circledR}$ (cyclosporine ophthalmic emulsion) $0.05 \%$ for topical ophthalmic use. Full prescribing information. Irvine, CA: Allergan; 2017.

61. Jones L, Downie LE, Korb D, et al. TFOS DEWS II management and therapy report. Ocul Surf. 2017;15(3):575-628. doi:10.1016/j. jtos.2017.05.006

62. Kymionis GD, Bouzoukis DI, Diakonis VF, Siganos C. Treatment of chronic dry eye: focus on cyclosporine. Clin Ophthalmol. 2008;2(4):829-836.

63. Ambroziak AM, Szaflik J, Szaflik JP, Ambroziak M, Witkiewicz J, Skopinski P. Immunomodulation on the ocular surface: a review. Cent Eur J Immunol. 2016;41(2):195-208. doi:10.5114/ceji.2016.60995

64. Meyer S, Kohler NG, Joly A. Cyclosporine A is an uncompetitive inhibitor of proteasome activity and prevents NF-kappaB activation. FEBS Lett. 1997;413(2):354-358. doi:10.1016/S0014-5793(97) 00930-7

65. Matsuda S, Koyasu S. Mechanisms of action of cyclosporine. Immunopharmacology. 2000;47(2-3):119-125. doi:10.1016/ S0162-3109(00)00192-2

66. Matsuda S, Moriguchi T, Koyasu S, Nishida E. T lymphocyte activation signals for interleukin-2 production involve activation of MKK6-p38 and MKK7-SAPK/JNK signaling pathways sensitive to cyclosporin A. J Biol Chem. 1998;273(20):12378-12382. doi:10.1074/jbc.273.20.12378

67. Ames P, Galor A. Cyclosporine ophthalmic emulsions for the treatment of dry eye: a review of the clinical evidence. Clin Investig (Lond). 2015;5(3):267-285. doi:10.4155/cli.14.135

68. Bang SP, Yeon CY, Adhikari N, et al. Cyclosporine A eyedrops with self-nanoemulsifying drug delivery systems have improved physicochemical properties and efficacy against dry eye disease in a murine dry eye model. PLoS One. 2019;14(11):e224805. doi:10.1371/journal.pone.0224805 
69. Demir T, Godekmerdan A, Balbaba N, Turkcuoglu P, Ilhan F, Demir N. The effect of infliximab, cyclosporine A and recombinant IL-10 on vitreous cytokine levels in experimental autoimmune uveitis. Indian J Ophthalmol. 2006;54(4):241-245. doi:10.4103/0301-4738.27948

70. Ghasemi H, Djalilian A. Topical calcineurin inhibitors: expanding indications for corneal and ocular surface inflammation J Ophthalmic Vis Res. 2019;14(4):398-399. doi: 10.18502/jovr. v14i4.5435

71. Davis G. The Evolution of Cataract Surgery. Mo Med. 2016;113 (1):58-62.

72. Salomao MQ, Ambrosio R Jr., Wilson SE. Dry eye associated with laser in situ keratomileusis: mechanical microkeratome versus femtosecond laser. J Cataract Refract Surg. 2009;35 (10):1756-1760. doi:10.1016/j.jcrs.2009.05.032

73. Kanellopoulos AJ. Incidence and management of symptomatic dry eye related to LASIK for myopia, with topical cyclosporine A. Clin Ophthalmol. 2019;13:545-552. doi:10.2147/OPTH.S188521

74. Iaccheri B, Torroni G, Cagini C, et al. Corneal confocal scanning laser microscopy in patients with dry eye disease treated with topical cyclosporine. Eye (Lond). 2017;31(5):788-794. doi:10.1038/eye.2017.3

75. Napoli PE, Braghiroli M, Iovino C, Demarinis G, Fossarello M. A study of refractory cases of persistent epithelial defects associated with dry eye syndrome and recurrent corneal erosions successfully treated with cyclosporine A $0.05 \%$ eye drops. Drug Des Devel Ther. 2019;13:2001-2008. doi:10.2147/DDDT. S207453

76. Napoli PE, Mangoni L, Gentile P, Braghiroli M, Fossarello M. A panel of broad-spectrum antivirals in topical ophthalmic medications from the drug repurposing approach during and after the coronavirus disease 2019 era. J Clin Med. 2020;9(8):2441. doi: $10.3390 / \mathrm{jcm} 9082441$

77. Sall K, Stevenson OD, Mundorf TK, Reis BL. Two multicenter, randomized studies of the efficacy and safety of cyclosporine ophthalmic emulsion in moderate to severe dry eye disease. CsA Phase 3 study group. Ophthalmology. 2000;107 (4):631-639. doi:10.1016/S0161-6420(99)00176-1

78. Stonecipher KG, Torkildsen GL, Ousler GW 3rd, Morris S, Villanueva L, Hollander DA. The IMPACT study: a prospective evaluation of the effects of cyclosporine ophthalmic emulsion $0.05 \%$ on ocular surface staining and visual performance in patients with dry eye. Clin Ophthalmol. 2016;10:887-895. doi:10.2147/OPTH.S101627

79. IKERVIS ${ }^{\circledR}$ (ciclosporin ophthalmic emulsion) $1 \mathrm{mg} / \mathrm{mL}$, for topical ophthalmic use. Full prescribing information. Evry, France: Santen SAS; 2015.

80. Leonardi A, Van Setten G, Amrane M, et al. Efficacy and safety of $0.1 \%$ cyclosporine A cationic emulsion in the treatment of severe dry eye disease: a multicenter randomized trial. Eur J Ophthalmol. 2016;26(4):287-296. doi:10.5301/ejo.5000779

81. CEQUA $^{\mathrm{TM}}$ (cyclosporine ophthalmic solution $0.09 \%$ ). Full prescribing information. Cranbury, NJ: Sun Pharmaceutical Industries, Inc.; 2018.

82. Vaishya RD, Khurana V, Patel S, Mitra AK. Controlled ocular drug delivery with nanomicelles. Wiley Interdiscip Rev Nanomed Nanobiotechnol. 2014;6(5):422-437. doi:10.1002/wnan.1272

83. Cholkar K, Gilger BC, Mitra AK. Topical, aqueous, clear cyclosporine formulation design for anterior and posterior ocular delivery. Transl Vis Sci Technol. 2015;4(3):1. doi:10.1167/ tvst.4.3.1

84. Goldberg DF, Malhotra RP, Schechter BA, Justice A, Weiss SL, Sheppard JD. A Phase 3, randomized, double-masked study of OTX-101 ophthalmic solution $0.09 \%$ in the treatment of dry eye disease. Ophthalmology. 2019;126(9):1230-1237. doi:10.1016/j. ophtha.2019.03.050
85. Malhotra R, Devries DK, Luchs J, et al. Effect of OTX-101, a novel nanomicellar formulation of Cyclosporine A, on corneal staining in patients with keratoconjunctivitis sicca: a pooled analysis of Phase $2 \mathrm{~b} / 3$ and Phase 3 studies. Cornea. 2019;38 (10):1259-1265. doi:10.1097/ICO.0000000000001989

86. Smyth-Medina R, Johnston J, Devries DK, et al. Effect of OTX-101, a novel nanomicellar formulation of Cyclosporine A, on conjunctival staining in patients with keratoconjunctivitis sicca: a pooled analysis of Phase $2 \mathrm{~b} / 3$ and 3 clinical trials. J Ocul Pharmacol Ther. 2019;35(7):388-394. doi:10.1089/ jop. 2018.0154

87. Tauber J, Schechter BA, Bacharach J, et al. A Phase II/III, randomized, double-masked, vehicle-controlled, dose-ranging study of the safety and efficacy of OTX-101 in the treatment of dry eye disease. Clin Ophthalmol. 2018;12:1921-1929. doi:10.2147/OPTH.S175065

88. Sheppard J, Kannarr S, Luchs J, et al. Efficacy and safety of OTX-101, a novel nanomicellar formulation of Cyclosporine A, for the treatment of keratoconjunctivitis sicca: pooled analysis of a Phase 2b/3 and Phase 3 study. Eye Contact Lens. 2020;46(Suppl 1):S14-s19. doi:10.1097/ICL.0000000000000636

89. Weiss SL, Kramer WG. Ocular distribution of cyclosporine following topical administration of OTX-101 in New Zealand White Rabbits. J Ocul Pharmacol Ther. 2019;35(7):395-402. doi:10.1089/jop.2018.0106

90. Mandal A, Gote V, Pal D, Ogundele A, Mitra AK. Ocular pharmacokinetics of a topical ophthalmic nanomicellar solution of Cyclosporine $\left(\right.$ Cequa $\left.^{\circledR}\right)$ for dry eye disease. Pharm Res. 2019;36 (2):36. doi:10.1007/s11095-018-2556-5

91. Pinheiro R, Panfil C, Schrage N, Dutescu RM. Comparison of the lubricant eyedrops Optive ${ }^{\circledR}$, Vismed Multi ${ }^{\circledR}$, and Cationorm ${ }^{\circledR}$ on the corneal healing process in an ex vivo model. Eur J Ophthalmol. 2015;25(5):379-384. doi:10.1089/jop.2015.0054

92. Schuerer N, Stein E, Inic-Kanada A, et al. Implications for ophthalmic formulations: ocular buffers show varied cytotoxic impact on human corneal-limbal and human conjunctival epithelial Cells. Cornea. 2017;36(6):712-718. doi:10.1097/ICO.0000000000001199

93. Abidi A, Shukla P, Ahmad A. Lifitegrast: a novel drug for treatment of dry eye disease. J Pharmacol Pharmacother. 2016;7 (4):194-198. doi:10.4103/0976-500X.195920

94. Chao W, Belmonte C, Benitez Del Castillo JM, et al. Report of the Inaugural Meeting of the TFOS $\mathrm{i}(2)=$ initiating innovation Series: targeting the Unmet Need for Dry Eye Treatment. Ocul Surf. 2016;14(2):264-316. doi:10.1016/j.jtos.2015.11.003

95. Xiidra ${ }^{\circledR}$ (lifitegrast ophthalmic solution) 5\%, for topical ophthalmic use. Full prescribing information. Lexington, MA: Shire; 2016

96. Perez VL, Pflugfelder SC, Zhang S, Shojaei A, Haque R. Lifitegrast, a novel integrin antagonist for treatment of dry eye disease. Ocul Surf. 2016;14(2):207-215. doi:10.1016/j.jtos.2016.01.001

97. Gaudana R, Ananthula HK, Parenky A, Mitra AK. Ocular drug delivery. AAPS J. 2010;12(3):348-360. doi:10.1208/s12248-0109183-3

98. Kunert KS, Tisdale AS, Stern ME, Smith JA, Gipson IK Analysis of topical cyclosporine treatment of patients with dry eye syndrome: effect on conjunctival lymphocytes. Arch Ophthalmol. 2000;118(11):1489-1496. doi:10.1001/ archopht.118.11.1489

99. Kunert KS, Tisdale AS, Gipson IK. Goblet cell numbers and epithelial proliferation in the conjunctiva of patients with dry eye syndrome treated with cyclosporine. Arch Ophthalmol. 2002;120(3):330-337. doi:10.1001/archopht.120.3.330

100. Jerkins GW, Pattare GR, Kannarr SR. A Review of Topical Cyclosporine A Formulations-A Disease-Modifying Agent for Keratoconjunctivitis Sicca. Clin Ophthalmol. 2020;14):481-489. doi:10.2147/OPTH.S228070. 


\section{Publish your work in this journal}

Clinical Ophthalmology is an international, peer-reviewed journal covering all subspecialties within ophthalmology. Key topics include: Optometry; Visual science; Pharmacology and drug therapy in eye diseases; Basic Sciences; Primary and Secondary eye care; Patient Safety and Quality of Care Improvements. This journal is indexed on PubMed

Submit your manuscript here: https://www.dovepress.com/clinical-ophthalmology-journal
Central and CAS, and is the official journal of The Society of Clinical Ophthalmology (SCO). The manuscript management system is completely online and includes a very quick and fair peer-review system, which is all easy to use. Visit http://www.dovepress.com/ testimonials.php to read real quotes from published authors. 